\title{
PRIEBEH JARNÝCH FENOLOGICKÝCH FÁZ NA GENERATÍVNYCH ORGÁNOCH AUTOCHTÓNNYCH POPULÁCIÍ SMREKA OBYČAJNÉHO (PICEA ABIES [L.] KARST.) ZO SLOVENSKA
}

\author{
JANA ŠKVARENINOVÁ \\ Technická univerzita vo Zvolene, Fakulta ekológie a environmentalistiky, \\ T. G. Masaryka 24, SK-960 53 Zvolen,e-mail: janask@vsld.tuzvo.sk
}

ŠKVARENInOVÁ J.: The course of spring phenological stages observed for the generative organs of Norway spruce (Picea abies [L.] Karst.) from its autochthonous populations in Slovakia. Lesn. Čas. - Forestry Journal, 56(4): 369 - 381, 2010, 9 fig., tab. 8., ref. 15. Original paper. ISSN $0323-10468$

The results of phenological observations of the generative organs of Norway spruce (Picea abies [L.] Karst.) in the Zvolen Basin are analysed. Twenty autochthonous spruce populations taken from its natural areas of distribution and planted in the Arboretum of Borova Hora belonging to the Technical University of Zvolen present the altitudinal range of 500-1,450 m. The $10 \%$ beginnings of phenological stages as a Flower buds swelling, a Formation of flowers before blossom, flowering and blossom fall were observed during the period of 2006-2008. Flower buds swelling occurred on its average from $12^{\text {th }}$ till $21^{\text {st }}$ of April and lasted 9-11 days predominantly. The formation of flowers before blossom occurred from the $23^{\text {rd }}$ of April till the $2^{\text {nd }}$ of May and lasted 5-6 days. The stage of Flowering began on its average from 29 $9^{\text {th }}$ April till $8^{\text {th }}$ May and predominantly lasted 5-6 days. Blossom fall occurred on average from $5^{\text {th }}$ till $17^{\text {th }}$ May and predominantly lasted 11-12 days. The earliest occurrence of phenological stages was recorded in years 2007 and 2008, while a moderate delay in the year of 2006 caused by low temperature and long lasting snow cover. Variation coefficients approached values from 0.57 up to $3.19 \%$. The equalization of air temperature course during the later spring period resulted in the observed decrease of variability of both the Flowering and Blossom fall. The altitude of original sites, the observed provenances come from, has not influenced neither the time of particular phenological stages beginnings nor the lengths of their periods. The conditions of a new environment proved to be decisive.

Key words: phenology, generative phenological phases, Norway spruce (Picea abies [L.] Karst.), autochthonous populations, Slovakia

Práca analyzuje výsledky fenologických pozorovaní na generatívnych orgánoch smreka obyčajného (Picea abies [L.] Karst.) vo Zvolenskej kotline. Dvadsał autochtónnych populácií smreka vysadených v Arboréte Borová hora Technickej univerzity 
vo Zvolene z jeho prirodzeného areálu rozšírenia na Slovensku predstavuje výškové rozpätie 500 - 1450 metrov. Počas rokov 2006-2008 sme sledovali 10\% nástup fenologických fáz pučania kvetných púčikov, butonizácie, kvitnutia a odkvet. Pučanie kvetných púčikov prebiehalo v danom období priemerne od 12. do 21. apríla, prevažne trvalo 9-11 dní. Butonizácia trvala od 23. apríla do 2. mája s najčastejšou dížkou 5-6 dní. Fenologická fáza kvitnutia začínala počas hodnoteného obdobia v priemere od 29. apríla do 8. mája väčšinou trvala 5-6 dní, odkvet prebiehal priemerne od 5 . do 17. mája a prevažne trval 11-12 dní. Nástupy fenologických fáz začínali najskôr v rokoch 2007 a 2008, s miernym oneskorením v roku 2006 vplyvom nízkych teplôt a dlhotrvajúcej snehovej pokrývky. Hodnoty variačných koeficientov sa pohybovali od 0,57 do 3,19\%. Vyrovnanie priebehu teplôt vzduchu v neskoršom jarnom období spôsobilo zníženie variability kvitnutia a odkvetu. Nástup a priebeh generatívnych fenologických fáz nezávisí od nadmorskej výšky ich pôvodného stanovišta, ale od podmienok nového prostredia. Nadmorská výška pôvodov smreka neovplyvnila ani dížku trvania fenologických fáz.

Klúčové slová: fenológia, generatívne fenologické fázy, smrek obyčajný (Picea abies [L.] Karst.), autochtónne populácie, Slovensko

\section{1. Úvod a problematika}

Fenológia v súčasnej dobe púta pozornoste nielen klimatológov, ale aj lesníkov, polnohospodárov a dalších odborníkov u nás aj v zahraničí. Hlavným dôvodom je poznanie vzájomných vztahov medzi vývojom klímy a fenologickými prejavmi rastlín, ako aj zákonitostí ich vývoja v rôznych klimatických oblastiach. Fenologické pozorovania sú cenným zdrojom informácií o dížke trvania vegetačného obdobia, o začiatku a ukončení dôležitých rastových a vývojových fáz rastlín v sledovanej oblasti (LARCHER 1988). Vplyvom klimatických zmien sa môžu nástupy fenologických fáz posunút a narušit d’alší vývoj rastlín. Rastliny, zvláše dreviny sa vyznačujú individuálnou a populačnou premenlivostou, ktorá je podmienená geneticky, evolučne a tiež vonkajším prostredím. Podla BAUERA (2006) jedince a populácie reagujú na vývoj klímy posunom fenologických fáz, zmenou reprodukčného procesu a zmenou štruktúry biocenóz.

Lesnícka fenológia má pre lesné hospodárstvo nezanedbatel'ný význam. Z dlhoročných fenologických záznamov (Hofman 1957, Petrovič 1972) možno stanovił napríklad najvhodnejšie termíny výsadby drevín v danej oblasti, termíny postrekov na ochranu proti škodcom a chorobám. Fenologické pozorovania lesných drevín môžu nájsł uplatnenie v špeciálnych lesníckych disciplínach akými sú škôlkarstvo, šlachtenie drevín a ich ochrana, ale aj pri charakteristike podmienok prostredia daného regiónu. Fenologické odchýlky jednotlivých drevín sú významné z hladiska genofondu (výberové stromy) a svoje miesto majú v pestovaní lesov hlavne pri vyznačovaní výchovných zásahov (ŠTEFANČík 1995, ŠKVARENINOVÁ 2003), ale aj pri plošnom a kontinuálnom sledovaní fenologických prejavov lesných ekosystémov a ich d'alšom vyhodnocovaní pomocou satelitných snímok (Priwitzer a kol. 2009). V rámci Slovenska je možné urči aj závislosti fenofáz od niektorých meteorologických faktorov a následne stanovį prognózu nástupných termínov fenofáz (Melo 2006). V súčasnosti sa fenologické pozorovania stávajú dôležitým biologickým indikátorom modelovania fenologických fáz pri 
možnom dopade klimatických zmien, ale aj pri prognózach d’alšieho rozšírenia a vitality drevín (Bagar \& NeKováŘ 2006, Menzel et al. 2008, ŠKVARENinová 2009b).

Táto práca podáva prehlad čiastočných výsledkov priebehu generatívnych fenologických fáz smreka obyčajného ovplyvnených novým prostredím. Môžeme tak získat cenné informácie o jeho fenologickej reakcii na teplotné zmeny, ktoré sa v budúcnosti dajú využit pri zakladaní porastov v oblastiach so zmenenými klimatickými podmienkami.

\section{Materiál a metódy}

Fenologické pozorovania sme vykonávali v rokoch 2006-2008 v chránenom areáli Arboréta Borová hora Technickej univerzity vo Zvolene. Územie sa rozprestiera na juhozápadných výbežkoch Zvolenskej pahorkatiny, ktorá patrí do orografického celku Zvolenskej kotliny. Nachádza sa v rozpätí nadmorských výšok od $291 \mathrm{~m}$ v severozápadnej časti do $377 \mathrm{~m}$ vo východnej časti. Podrobnejšia klimatická charakteristika lokality je uvedená v práci ŠKVARENINOVEJ (2009a). Predmetom pozorovania boli skupiny smreka obyčajného získané z 20 lokalít Slovenska, kde sa táto drevina vyskytuje v pôvodných lesných spoločenstvách. Predstavujú vzácny genetický materiál z 9 orografických celkov z nadmorských výšok 500-1 450 metrov. Tieto boli sústredené a vysadené v rokoch 1980-1984 do rovnakých podmienok prostredia na území chráneného areálu.

V každej skupine, ktorá predstavuje jeden pôvod sme vybrali 10 jedincov tak, aby boli rovnako zastúpené vzhladom k orientácii svetových strán aj postaveniu v skupine. Postupovali sme podla metodiky vypracovanej SHMÚ v Bratislave (KoLEKTív 1984). Výsadby sú situované v čiastočne odlišných podmienkach aké majú lesné porasty, preto nebolo možné úplne dodržat zásady uvedenej metodiky pre hlavné dreviny. Veková hranica populácií, ktoré tvoria hlavný porast a prinášajú úrodu zodpovedá podmienkam výberu doplnkových drevín. Bol vylúčený vplyv porastového okraja na priebeh fenologických fáz. Pri každej fenologickej fáze sme zaznamenali jej začiatok (10\%), ktorý dosiahlo aspoň $10 \%$ stromov a $100 \%$ výskyt, ktorý bol potrebný na zistenie dížky jej trvania.

Pri spracovaní sme dátumy nahradili ich poradovým číslom od začiatku roka. Pozorovali sme nasledovné generatívne fenologické fázy:

- pučanie kvetných púčikov - PKP (kvetné púčiky vplyvom rastu zväčšili svoj objem a na okrajoch obalových šupín sa objavilo bledozelené sfarbenie - obr. 1),

- butonizácia - BU (samčie kvety začínajú napučiavał, ale ešte neprášia pel’ - obr. 2),

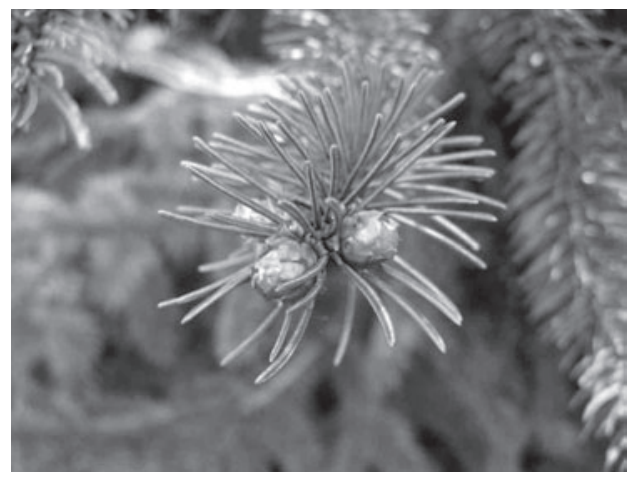

Obr. 1. Pučanie kvetných púčikov

Fig. 1. Flower buds swelling.

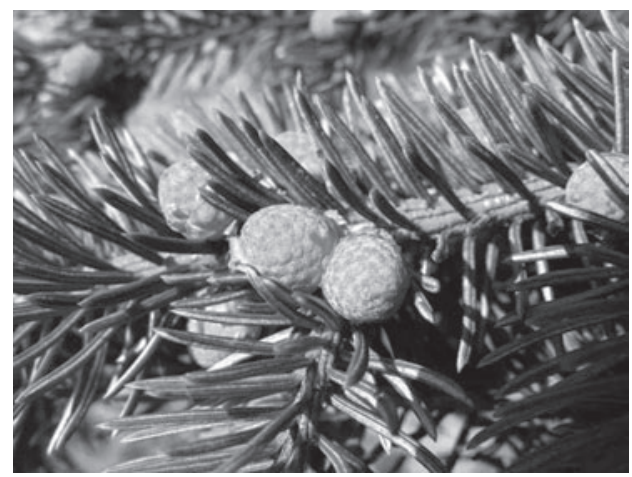

Obr. 2. Butonizácia

Fig. 2. Formation of flowers before blossom. 


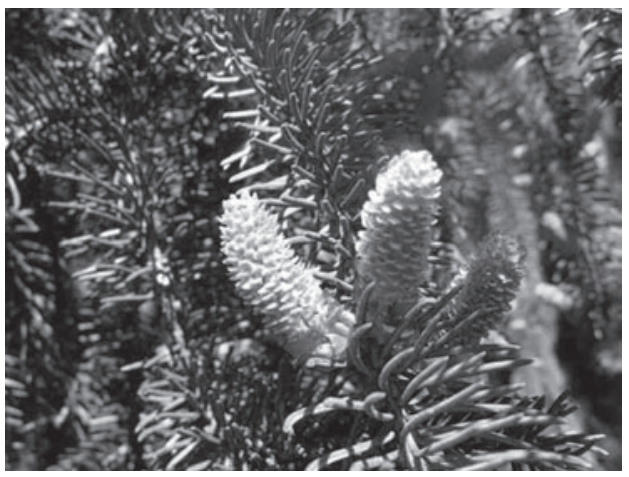

Obr. 3. Kvitnutie

Fig. 3. Flowering.

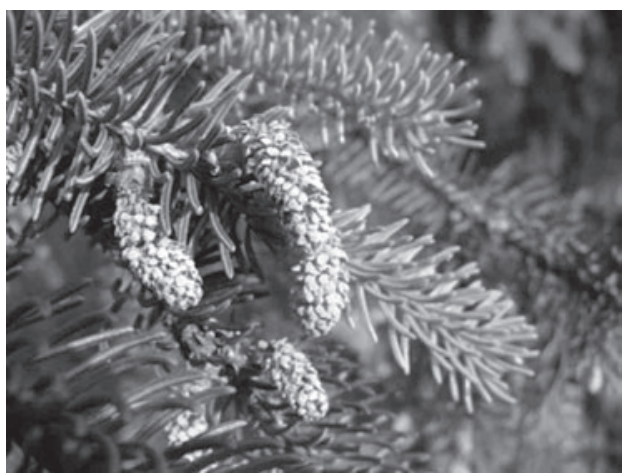

Obr. 4. Odkvet

Fig. 4. Blossom fall.

Tabul'ka 1. Charakteristika pôvodov smreka obyčajného (Picea abies [L.] Karst.) v Arboréte Borová hora

Table 1. Characteristics of spruce (Picea abies [L.] Karst.) autochthonous populations in the Arboretum Borová hora

\begin{tabular}{|c|c|c|c|}
\hline Výšková skupina'1) & Číslo pôvodu' ${ }^{2)}$ & Orografický celok ${ }^{3)}$ & $\begin{array}{c}\text { Nadmorská výška } \\
(\mathbf{m})^{4)}\end{array}$ \\
\hline $\begin{array}{c}1 \\
500-700 \mathrm{~m} \mathrm{n} . \mathrm{m}\end{array}$ & $\begin{array}{l}1 \\
2 \\
3 \\
4 \\
5 \\
6 \\
7\end{array}$ & $\begin{array}{c}\text { Volovské vrchy } \\
\text { Spišsko-gemerský kras } \\
\text { Štiavnické vrchy } \\
\text { Volovské vrchy } \\
\text { Spišsko-gemerský kras } \\
\text { Spišsko-gemerský kras } \\
\text { Pobeskydská vrchovina }\end{array}$ & $\begin{array}{l}500 \\
600 \\
600 \\
600 \\
620 \\
620 \\
650\end{array}$ \\
\hline$\underset{710-950 \mathrm{~m} \mathrm{n} . \mathrm{m} .}{2}$ & $\begin{array}{c}8 \\
9 \\
10 \\
11 \\
12 \\
13\end{array}$ & $\begin{array}{c}\text { Oravské Beskydy } \\
\text { Volovské vrchy } \\
\text { Pobeskydská vrchovina } \\
\text { Javorníky } \\
\text { Oravské Beskydy } \\
\text { Volovské vrchy }\end{array}$ & $\begin{array}{l}750 \\
750 \\
850 \\
950 \\
950 \\
950\end{array}$ \\
\hline $\begin{array}{c}\mathbf{3} \\
960-1450 \mathrm{~m} \mathrm{n.m} .\end{array}$ & $\begin{array}{l}14 \\
15 \\
16 \\
17 \\
18 \\
19 \\
20\end{array}$ & $\begin{array}{c}\text { Nízke Tatry } \\
\text { Volovské vrchy } \\
\text { Nízke Tatry } \\
\text { Volovské vrchy } \\
\text { Podtatranská kotlina } \\
\text { Nízke Tatry } \\
\text { Západné Tatry }\end{array}$ & $\begin{array}{ll}1 & 000 \\
1 & 060 \\
1 & 100 \\
1 & 100 \\
1 & 200 \\
1 & 380 \\
1 & 450\end{array}$ \\
\hline
\end{tabular}

${ }^{1)}$ Altitudinal zone, ${ }^{2)}$ Number of origin, ${ }^{3)}$ Orographic unit, ${ }^{4}$ Altitude (m) 
- kvitnutie $-K V$ (samčie kvety prášia pel - obr. 3),

- odkvet - OD (samčie kvety prestali prášit pel', zosychajú a začínajú opadávat - obr. 4).

Všetky sledované pôvody sme rozdelili podla nadmorskej výšky do 3 skupín tak, aby rozpätia nadmorských výšok mali približne rovnako vel'ký interval a pôvody boli rozmiestnené do skupín v čo najvyrovnanejšom počte. Prehlad rozdelenia pôvodov smreka v jednotlivých skupinách podáva tabul'ka 1.

Štatistickú významnosỉ rozdielov medzi výberovými priemermi výškových skupín pri nástupe fenologických fáz sme vyhodnotili v programe Statistica pomocou T-testu.

\section{Výsledky a diskusia}

V rokoch 2006-2008 fenofáza pučania kvetných púčikov prebiehala na všetkých sledovaných pôvodoch priemerne od 12. do 21. apríla (tab. 2). Najskorší nástup začal 9. apríla 2007 pri pôvode z 1. výškovej skupiny pochádzajúcom z nadmorskej výšky 650 m. Najneskorší termín sme zaznamenali 22. apríla 2006 a 2008 pri 6 pôvodoch z 2. a 3. výškovej skupiny (950-1 $450 \mathrm{~m}$ n. m.). Z tabul'ky 2 a obrázku 5 vidiet, že táto fenologická fáza nastupovala v jednotlivých výškových skupinách postupne

Tabulka 2. Štatistické charakteristiky fenofázy pučania kvetných púčikov vo výškových skupinách

Table 2. Statistical characteristics obtained during the phenological phase of the blossom buds swelling in the observed altitudinal groups

\begin{tabular}{|c|c|c|c|c|c|c|c|c|c|c|c|c|}
\hline \multirow{2}{*}{$\begin{array}{c}\begin{array}{c}\text { Výšková } \\
\text { skupina }\end{array} \\
\text { Roky }^{2}\end{array}$} & \multicolumn{4}{|c|}{$\begin{array}{c}1(500-700 \mathrm{~m} \mathrm{n} . \mathrm{m} .) \\
n=7\end{array}$} & \multicolumn{4}{|c|}{$\begin{array}{c}2(710-950 \mathrm{~m} n . \mathrm{m} .) \\
n=6\end{array}$} & \multicolumn{4}{|c|}{$\begin{array}{c}3(960-1450 \text { m n. m.) } \\
n=7\end{array}$} \\
\hline & $\varnothing$ & $\min$ & $\max$ & $\mathrm{s}_{\mathrm{x}} \%$ & $\varnothing$ & $\min$ & $\max$ & $\mathrm{s}_{\mathrm{x}} \%$ & $\varnothing$ & $\min$ & max & $\mathrm{s}_{\mathrm{x}} \%$ \\
\hline 2006 & 17.4 & 15.4 . & 20 & 1, & 20.4 & 18.4 . & 22.4 & 1,33 & 21.4 . & 20.4 . & 22.4. & 0,89 \\
\hline 2007 & 12.4. & & & & 14.4. & 12.4. & & & 15.4. & 12.4. & & 1,01 \\
\hline 2008 & 15.4 . & 10.4 . & 18.4 . & 3,19 & 18.4 . & 16.4 . & 22.4 . & 2,25 & 17.4 . & 16.4 . & 20.4 . & 1,30 \\
\hline
\end{tabular}

$\varnothing$ - priemerný nástup fenologickej fázy - average beginning of blossoming, min - najskorší nástup - the earliest beginning, max - najneskorší nástup - the latest beginning, $\mathrm{s}_{\mathrm{x}} \%$ - variačný koeficient - variation coefficient.

${ }^{1)}$ Altitudinal range, ${ }^{2)}$ Years

Tabulka 3. Počet dní v mesiaci so snehovou pokrývkou na stanici Sliač v rokoch 2006-2008 Table 3. Number of days in a month with snow cower at the station Sliač during the period 2006-2008

\begin{tabular}{|c|c|c|c|}
\hline Rok $^{\mathbf{1}}$ & $\mathbf{2 0 0 6}$ & $\mathbf{2 0 0 7}$ & $\mathbf{2 0 0 8}$ \\
\hline Január $^{2)}$ & 31 & 13 & 22 \\
\hline Február $^{3)}$ & 28 & 10 & 0 \\
\hline Marec $^{4)}$ & 28 & 1 & 4 \\
\hline Aprí1 $^{()}$ & 0 & 0 & 0 \\
\hline Máj() $^{6}$ & 0 & 0 & 0 \\
\hline Jún $^{7)}$ & 0 & 0 & 0 \\
\hline
\end{tabular}

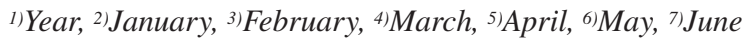




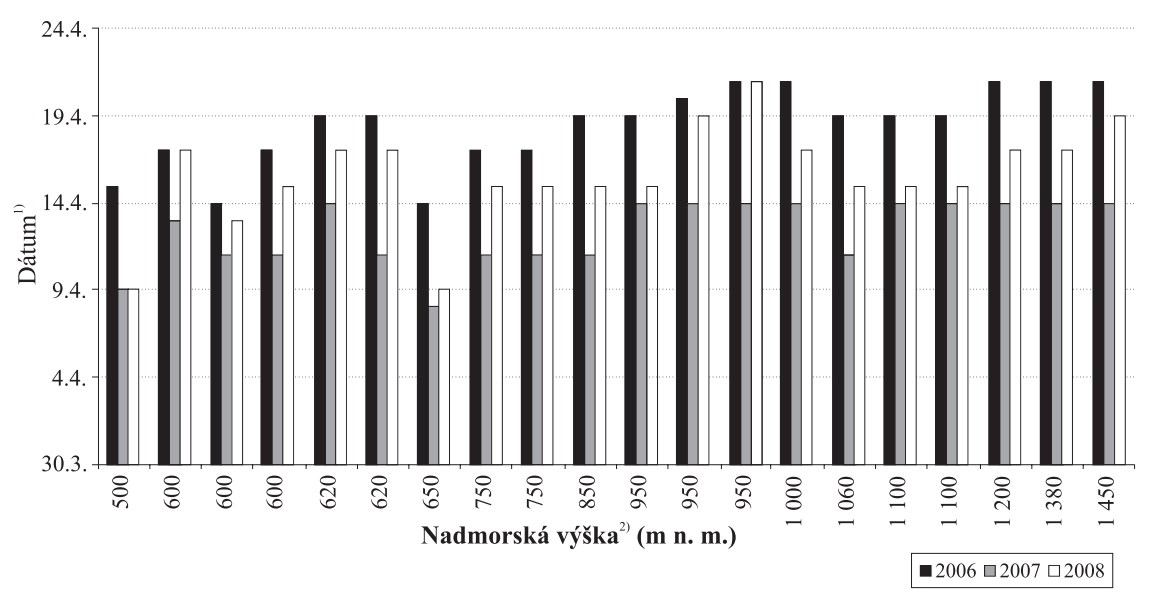

Obr. 5. Nástup a dížka trvania fenofázy „pučanie kvetných púčikov“ jednotlivých pôvodov podla nadmorskej výšky v rokoch 2006-2008

Fig. 5. Beginning and duration of the phenophase "blossom buds swelling" of autochthonous populations according to altitude in the years 2006-2008.

${ }^{1)}$ Date, ${ }^{2)}$ Altitude (a.s.l.)

Tabul'ka 4. Počet dní trvania generatívnych fenologických fáz smreka obyčajného podla skupín v rokoch 2006-2008

Table 4. Duration (in days) of individual generative phenophases in Norway spruce, according to autochthonous populations in years 2006-2008

\begin{tabular}{|c|c|c|c|c|c|c|}
\hline Fenofáza $^{1)}$ & \multicolumn{3}{|c|}{ Pučanie kvetných púčikov²) } & \multicolumn{3}{|c|}{ Butonizácia $^{3)}$} \\
\hline Roky & 1 & 2 & 3 & 1 & 2 & 3 \\
\hline 2006 & $8-11$ & $8-11$ & $8-11$ & $5-7$ & $5-6$ & $5-6$ \\
\hline 2007 & $8-10$ & $8-11$ & $9-11$ & $5-6$ & $5-6$ & $5-6$ \\
\hline 2008 & $8-11$ & $8-10$ & $7-11$ & $5-7$ & $5-7$ & $5-6$ \\
\hline Fenofáza $^{1)}$ & \multicolumn{3}{|c|}{ Kvitnutie $^{5)}$} & \multicolumn{3}{|c|}{ Odkvet') $^{6}$} \\
\hline Roky ${ }^{4)}$ & 1 & 2 & 3 & 1 & 2 & 3 \\
\hline 2006 & $5-7$ & $5-7$ & $5-7$ & $12-14$ & $11-13$ & $11-13$ \\
\hline 2007 & $4-5$ & $5-6$ & $5-6$ & $11-12$ & $11-12$ & $10-14$ \\
\hline 2008 & $5-6$ & $5-7$ & $5-6$ & $10-13$ & $10-12$ & $12-14$ \\
\hline
\end{tabular}

${ }^{1)}$ Phenological phase, ${ }^{2}$ Flower buds swelling, ${ }^{3)}$ Formation of flowers before blossom, ${ }^{4}$ Years, ${ }^{5}$ Flowering, ${ }^{6)}$ Blossom fall

s priemerným oneskorením 1-3 dni v rámci jedného roku, hoci pri viacerých pôvodoch z rôznych výškových tried sme v každom roku zaznamenali aj zhodný termín nástupu. Miera variability vyjadrená variačným koeficientom sa pohybovala od $0,89 \%$ do $3,19 \%$, pričom najvyššie hodnoty boli zistené v roku 2008. Nástup a priebeh tejto 


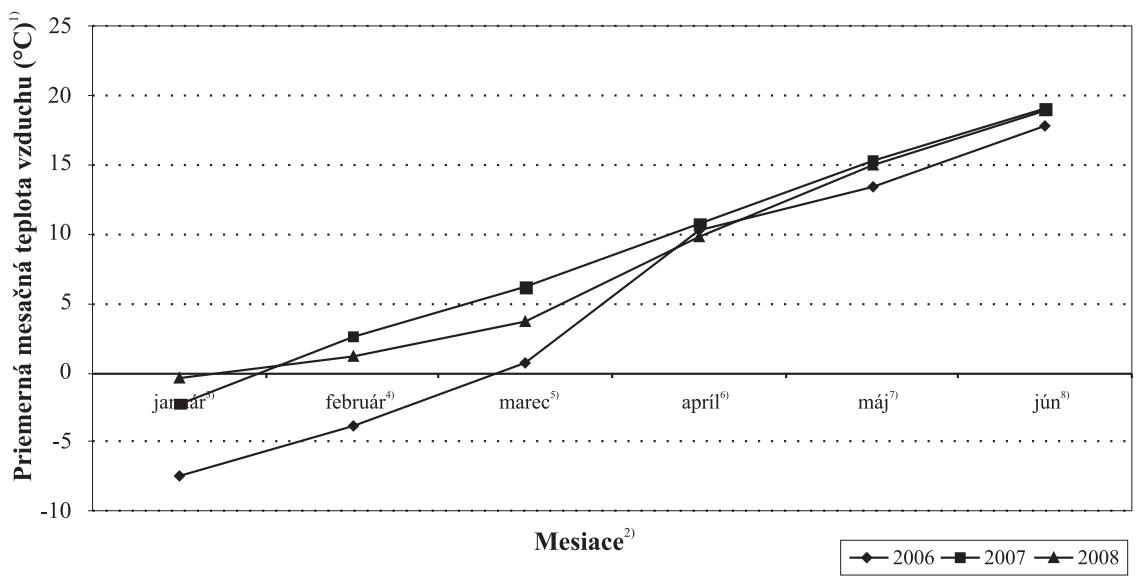

Obr. 6. Priemerné mesačné teploty vzduchu v rokoch 2006-2008 na stanici Sliač

Fig. 6. Average monthly air temperatures at the station Sliač during the period 2006-2008. ${ }^{1)}$ Average monthly air temperature, ${ }^{2}$ Months, ${ }^{3)}$ January, ${ }^{4)}$ February, ${ }^{5}$ March, ${ }^{6}$ April, ${ }^{7)}$ May, 8) June

fenologickej fázy v jednotlivých rokoch súvisel s priebehom teplôt vzduchu a snehovou pokrývkou v jarných mesiacoch. Údaje o priemerných mesačných teplotách a počte dní so snehom uvádza obrázok 6 a tabulka 3. V najchladnejšom roku 2006, kedy priemerná marcová teplota vzduchu dosiahla len $0,7^{\circ} \mathrm{C}$ a sneh sa udržal 28 dní v mesiaci, nástup a priebeh tejto, ale aj ostatných fenologických fáz sa posunul do neskoršieho obdobia. Sledovali sme aj dížku trvania fenofázy, ktorej výsledky sú zaznamenané v tabul'ke 4. Zistili sme, že pučanie kvetných púčikov prebiehalo v rozpätí 7 až 11 dní, pričom najčastejšie trvalo pri všetkých pôvodoch nezávisle od nadmorskej výšky 9-10 dní.

Butonizácia trvala počas sledovaných rokov priemerne od 23. apríla do 2. mája. Priebeh v jednotlivých skupinách podáva tabul'ka 5 a obrázok 7. Najskorší nástup sme zaznamenali 20. apríla 2007 v 1. výškovej skupine pri pôvode z Volovských vrchov z nadmorskej výšky 500 metrov. Pri pôvodoch z 2 . výškovej skupiny $(950 \mathrm{~m})$ nastúpila butonizácia najneskôr 4. mája 2006. Vo viacerých prípadoch sa v tom istom roku táto fenofáza začínala rovnako vo všetkých výškových skupinách. Najskorší dátum nástupu bol 20. apríla 2007 pri pôvode 1 z Volovských vrchov z nadmorskej výšky 500 metrov. Najneskorší termín nástupu pripadol na 4. máj 2006. Zaznamenali sme ho na 4 pôvodoch z 1. a 2. skupiny. Variabilita sa v porovnaní s predchádzajúcou fenofázou znížila vplyvom vyrovnanejších teplôt vzduchu. Dokumentujú to aj hodnoty variačných koeficientov, ktoré sa pohybujú v intervale od $0,57 \%$ do 2,32 \%. DÍžka trvania fenofázy (tab. 4) bola vo všetkých skupinách pôvodov najčastejšie 5-6 dní. Najdlhší interval predstavoval 7 dní v rokoch 2006 a 2008.

Fenologická fáza kvitnutia prebiehala na všetkých pôvodoch v arboréte priemerne od 29. apríla do 8. mája (tab. 6). Najskorší nástup pripadol na 27. apríl 2007 v 1. 
Tabul'ka 5. Štatistické charakteristiky fenofázy butonizácia vo výškových skupinách Table 5. Statistical characteristics obtained during the phenological phase of the formation of flowers before blossom in the observed altitudinal groups

\begin{tabular}{|c|c|c|c|c|c|c|c|c|c|c|c|c|}
\hline $\begin{array}{l}\text { Výšková } \\
\text { skupina }^{1)}\end{array}$ & \multicolumn{4}{|c|}{$\begin{array}{c}1(500-700 \mathrm{~m} \mathrm{n} . \mathrm{m} .) \\
n=7\end{array}$} & \multicolumn{4}{|c|}{$\begin{array}{c}2(710-950 \mathrm{~m} \mathrm{n} . \mathrm{m} .) \\
n=6\end{array}$} & \multicolumn{4}{|c|}{$\begin{array}{c}3(960-1450 \text { m n. m.) } \\
n=7\end{array}$} \\
\hline Roky $^{2)}$ & $\varnothing$ & $\min$ & $\max$ & $\mathrm{s}_{\mathrm{x}} \%$ & $\varnothing$ & $\min$ & $\max$ & $\mathrm{s}_{\mathrm{x}} \%$ & $\varnothing$ & Min & $\max$ & $\mathrm{s}_{\mathrm{x}} \%$ \\
\hline 2006 & 1.5. & 27.4 . & & 2,12 & 2.5 & 30.4 . & & 1,34 & 2.5 & 2.5 . & 5. & 0,57 \\
\hline 2007 & 23.4 . & 20.4 . & 25.4 . & 1,49 & 25.4 . & 23.4 . & 28.4 . & 1,59 & 26.4 . & 24.4. & 29.4 . & 1,38 \\
\hline 2008 & 27.4 . & 22.4 . & 30.4 . & 2,32 & 29.4 . & 27.4 . & 1.5 & 1,27 & 27.4 . & 25.4 . & 1.5 & 1,86 \\
\hline
\end{tabular}

$\varnothing$ - priemerný nástup fenologickej fázy - average beginning of blossoming, min - najskorší nástup - the earliest beginning, max - najneskorší nástup - the latest beginning, $\mathrm{s}_{\mathrm{x}} \%$ - variačný koeficient - variation coefficient.

${ }^{1)}$ Altitudinal group, ${ }^{2}$ Years

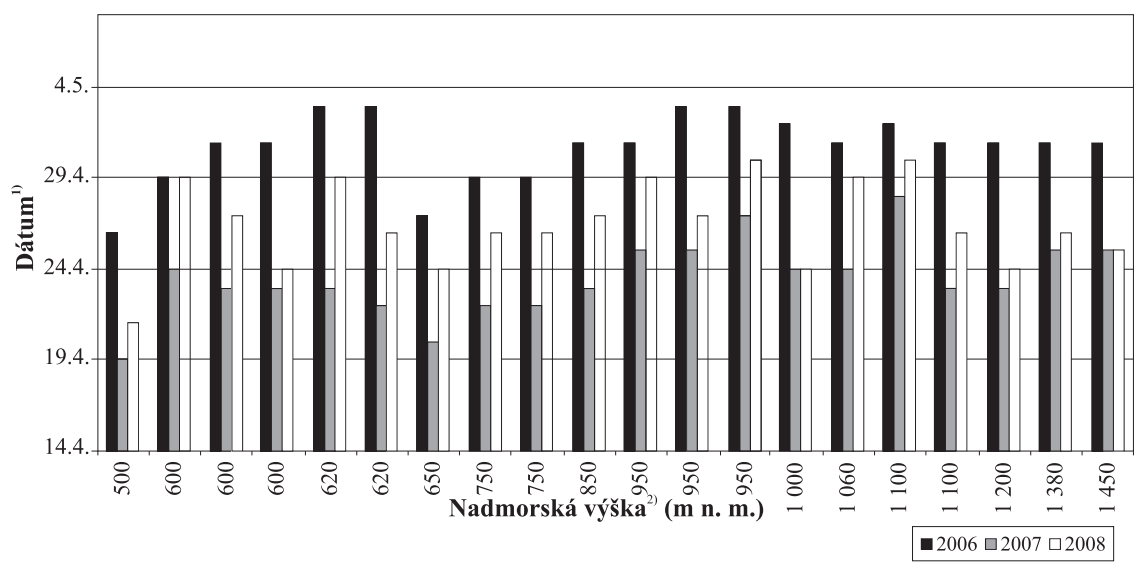

Obr. 7. Nástup a dížka trvania fenofázy „butonizácia“ jednotlivých pôvodov podla nadmorskej výšky v rokoch 2006-2008

Fig. 7. Beginning and duration of the phenophase "formation of flowers before blossom" of autochthonous populations according to altitude in the years 2006-2008.

${ }^{1)}$ Date, ${ }^{2}$ Altitude (a.s.l.)

skupine, najneskorší na 10. máj 2006 vo všetkých skupinách pôvodov. LukNÁRová (2000) v práci uvádza v rokoch 1986-1998 nástup tejto fenofázy v nadmorskej výške do 500 metrov priemerne 3.-19. mája. Nad 500 metrov zistila začiatok kvitnutia od 12. do 28. mája, čo je v porovnaní s našimi výsledkami oneskorenie o 13 až 20 dní. Tento jav je s vysokou pravdepodobnostou spôsobený teplotnými pomermi stanovišta. Podobne aj v neskoršom období rokov 1961-1985 (LuKNÁROvÁ 2000) bolo zaznamenané oneskorenie začiatku kvitnutia smreka v rámci Slovenska o 4-18 dní, pričom 
oneskorenie súviselo s nadmorskou výškou lokality. Fenofáza u našich pôvodov nastupovala súčasne vo všetkých skupinách. Skorší a pomerne časovo vyrovnaný bol nástup v rokoch 2007 a 2008 pri všetkých pôvodoch, oneskorenie sme zaznamenali v roku 2006 (obr. 8). Dížka trvania fenofázy (tab. 4) predstavovala vo všetkých skupinách pôvodov najčastejšie interval 5-6 dní. Najkratší interval dosiahol v roku 2007 v 1. skupine pôvodov 4 dni, najdlhší predstavoval v rokoch 2006 a 2008 vo všetkých skupinách dĺžku 7 dní. Priebeh teplôt vzduchu bez výrazných teplotných výkyvov

Tabulka 6. Štatistické charakteristiky fenofázy kvitnutie vo výškových skupinách Table 6. Statistical characteristics obtained during the phenological phase -flowering in the observed altitudinal groups

\begin{tabular}{|c|c|c|c|c|c|c|c|c|c|c|c|c|}
\hline \multirow{2}{*}{$\begin{array}{c}\begin{array}{c}\text { Výšková } \\
\text { skupina }\end{array} \\
\text { Roky }^{2}\end{array}$} & \multicolumn{4}{|c|}{$\begin{array}{c}1(500-700 \mathrm{~m} \mathrm{n} . \mathrm{m} .) \\
n=7\end{array}$} & \multicolumn{4}{|c|}{$\begin{array}{c}2(710-950 \mathrm{~m} \mathrm{n} . \mathrm{m} .) \\
n=6\end{array}$} & \multicolumn{4}{|c|}{$\begin{array}{c}3 \text { (960-1 } 450 \text { m n. m.) } \\
n=7\end{array}$} \\
\hline & $\varnothing$ & $\min$ & $\max$ & $\mathrm{s}_{\mathrm{x}} \%$ & $\varnothing$ & $\min$ & $\max$ & $\mathrm{s}_{\mathrm{x}} \%$ & $\varnothing$ & Min & $\max$ & $\mathrm{s}_{\mathrm{x}} \%$ \\
\hline 2006 & 8.5 . & 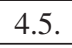 & & 1,87 & 8.5 & & 10 & & 8. & 7.5. & 10.5 & 0,92 \\
\hline 2007 & 29.4 . & 27.4 . & 30.4 . & 0,94 & 1.5 . & 29.4 . & 4.5. & 1, & 2.5 . & 30.4 . & 4.5 . & 1,15 \\
\hline 2008 & 3.5 & 28.4 . & 5.5 & 1,88 & 4.5 . & 2.5 & 6.5 & 1,09 & 2.5 & 29.4 . & 6.5 . & 2,10 \\
\hline
\end{tabular}

$\varnothing$ - priemerný nástup fenologickej fázy - average beginning of blossoming, min - najskorší nástup - the earliest beginning, max - najneskorší nástup - the latest beginning, $\mathrm{s}_{\mathrm{x}} \%$ - variačný koeficient - variation coefficient.

1)Altitudinal group, ${ }^{2}$ Years

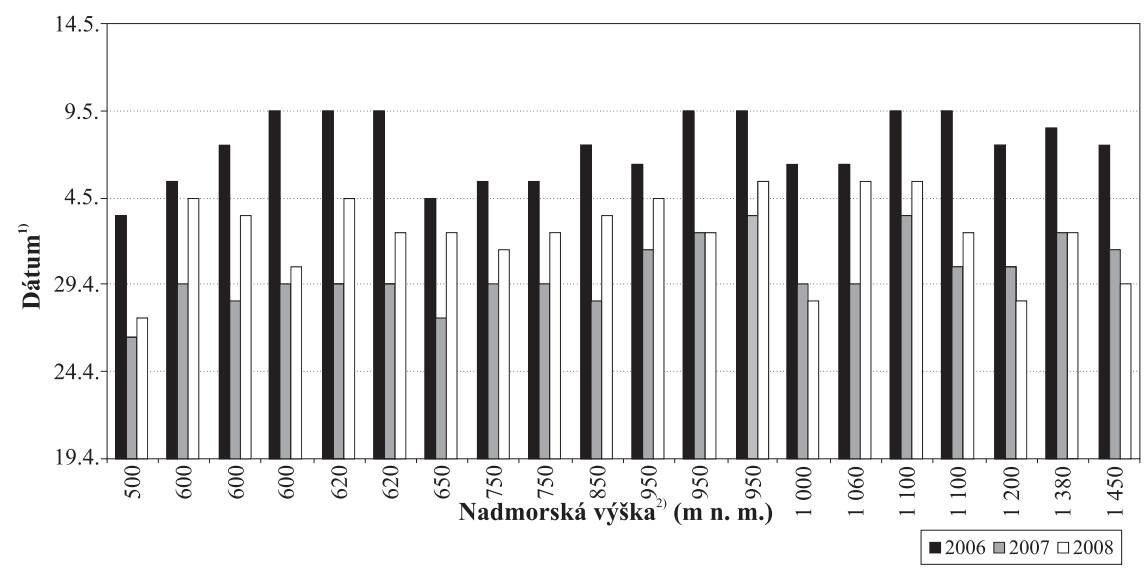

Obr. 8. Nástup a dížka trvania fenofázy „kvitnutie“ jednotlivých pôvodov podla nadmorskej výšky v rokoch 2006-2008

Fig. 8. Beginning and duration of the phenophase "flowering" of autochthonous populations according to the altitude in the years 2006-2008.

${ }^{1)}$ Date, ${ }^{2)}$ Altitude (a.s.l.) 
v neskoršom jarnom období spôsobil takmer rovnaký nástup a dížku trvania kvitnutia vo všetkých skupinách. Dokumentujú to aj vyrovnané variačné koeficienty, ktoré sa pohybovali v rozpätí od $0,92 \%$ do $2,1 \%$. Časové rozdiely medzi skupinami z rôznych nadmorských výšok sú vyrovnané. $Z$ týchto poznatkov môžeme konštatovat, že zmena stanovišta výrazne neovplyvňuje nástup kvitnutia sledovaných pôvodov podla výškových skupín, čo je podstatný rozdiel oproti nástupu vegetatívnych fenologických fáz pri týchto populáciách (ŠKVARENINOVÁ 2009a).

Tabulka 7. Štatistické charakteristiky fenofázy odkvet vo výškových skupinách

Table 7. Statistical characteristics obtained during the phenological phase of the blossom fall in the observed altitudinal groups

\begin{tabular}{|c|c|c|c|c|c|c|c|c|c|c|c|c|}
\hline $\begin{array}{l}\text { Výšková } \\
\text { skupina }^{1)}\end{array}$ & \multicolumn{4}{|c|}{$\begin{array}{c}1(500-700 \mathrm{~m} \mathrm{n} . \mathrm{m} .) \\
n=7\end{array}$} & \multicolumn{4}{|c|}{$\begin{array}{c}2(710-950 \mathrm{~m} \mathrm{n} . \mathrm{m} .) \\
n=6\end{array}$} & \multicolumn{4}{|c|}{$\begin{array}{c}3(960-1450 \text { m n. m.) } \\
n=7\end{array}$} \\
\hline Roky $^{2)}$ & $\varnothing$ & $\min$ & $\max$ & $\mathrm{s}_{\mathrm{x}} \%$ & $\varnothing$ & $\min$ & $\max$ & $\mathrm{s}_{\mathrm{x}} \%$ & $\varnothing$ & Min & $\max$ & $\mathrm{s}_{\mathrm{x}} \%$ \\
\hline 2006 & 16.5 . & 12.5. & 19.5. & 2,06 & 17.5 . & 15.5. & 19.5 . & 1,32 & 17.5. & 16.5 . & 19.5 . & 1,08 \\
\hline 2007 & 5.5 . & 4.5. & 8.5 . & 0,94 & 9.5. & 7.5 . & 12.5. & 1,52 & 9.5 . & 7.5 & 11.5 . & 1,27 \\
\hline 2008 & 10.5 . & 7.5 & 12.5 . & 1,53 & 12.5 . & 10.5 . & 14.5. & 1,04 & 11.5 . & 8.5 & 14.5. & 1,78 \\
\hline
\end{tabular}

$\varnothing$ - priemerný nástup fenologickej fázy - average beginning of blossoming, min - najskorší nástup - the earliest beginning, max - najneskorší nástup - the latest beginning, $\mathrm{s}_{\mathrm{x}} \%$ - variačný koeficient - variation coefficient.

1)Altitudinal group, ${ }^{2)}$ Years

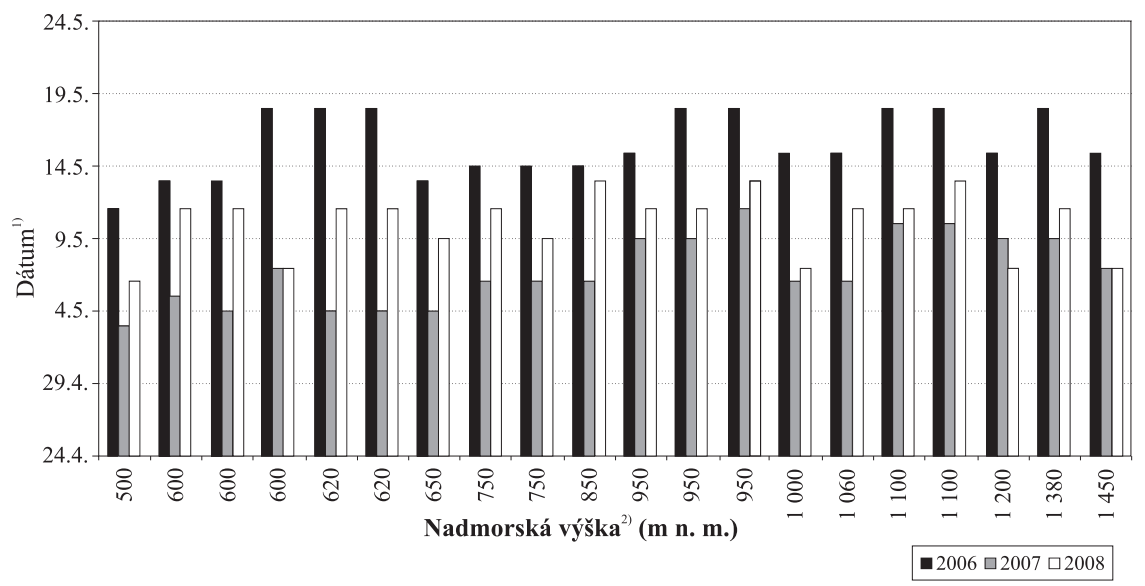

Obr. 9. Nástup a dížka trvania fenofázy „odkvet“ jednotlivých pôvodov podla nadmorskej výšky v rokoch $2006-2008$

Fig. 9. Entrance and duration of the phenophase "blossom fall" autochthonous populations according to the altitude in the years 2006-2008.

${ }^{1)}$ Date, ${ }^{2)}$ Altitude (a.s.l.) 
Fenologická fáza odkvet trvala v priemere od 5. do 17. mája (tab. 7). Najskôr začínala 4. mája 2007 pri pôvode z Volovských vrchov z nadmorskej výšky 500 metrov. Najneskorší dátum nástupu sme zaznamenali 19. mája 2006 pri 8 pôvodoch vo všetkých skupinách. Aj napriek vyrovnaným priemerným májovým teplotám vzduchu počas hodnoteného obdobia (obr. 6) došlo v roku 2006 k miernemu oneskoreniu nástupu fenofázy u niektorých pôvodov, čo pravdepodobne súviselo s vývojom teplôt $\mathrm{v}$ predchádzajúcich mesiacoch. Fenofáza nastupovala $\mathrm{v}$ jednotlivých rokoch $\mathrm{v}$ rovnakom čase na viacerých pôvodoch bez rozdielu nadmorskej výšky, z ktorej jednotlivé pôvody pochádzajú (obr. 9). Priemerná dížka odkvetu sa pohybovala v intervale 11-12 dní, pri niektorých pôvodoch dosahovala 10-14 dní. Nízku variabilitu dokumentuje aj najkratšie rozpätie variačných koeficientov $(0,94-2,06 \%)$ v porovnaní s predchádzajúcimi fenologickými fázami.

Sledovali sme aj štatistickú významnosê rozdielov priemerov jednotlivých fenologických fáz medzi výškovými skupinami. Z výsledkov v tabul'ke 8 vidieł, že medzi priemermi pôvodov z 1., 2. a 3. skupiny väčšinou neexistujú štatisticky významné rozdiely. Tieto sa potvrdili len v štyroch prípadoch, pri $95 \%$ spolahlivosti. Nástup jednotlivých generatívnych fenologických fáz a ich časový posun nezávisí od nadmorskej výšky pôvodov. V jednom termíne prebieha fenofáza na viacerých pôvodoch z rôznych nadmorských výšok, čo dokumentujú aj predchádzajúce grafické výsledky práce.

Tabulka 8. Štatistická významnosî rozdielov medzi výberovými priemermi výškových skupín jednotlivých fenologických fáz

Table 8. Evaluation of a statistical significance of differences among sample means observed in all altitudinal groups during particular phenological stages

\begin{tabular}{|c|c|c|c|}
\hline \multirow{2}{*}{ Fenologické fázy ${ }^{1)}$} & \multicolumn{3}{|c|}{ Štatistická významnost medzi výškovými skupinami ${ }^{2}$} \\
\cline { 2 - 4 } & $\mathbf{1 - 2}$ & $\mathbf{1 - 3}$ & $\mathbf{2 - 3}$ \\
\hline $\mathrm{PKP}-2006$ & 0,103 & $0,036^{*}$ & 0,382 \\
\hline $\mathrm{PKP}-2007$ & 0,229 & 0,077 & 0,398 \\
\hline $\mathrm{PKP}-2008$ & 0,278 & 0,395 & 0,571 \\
\hline $\mathrm{BU}-2006$ & 0,599 & 0,542 & 1,000 \\
\hline $\mathrm{BU}-2007$ & 0,105 & 0,089 & 1,000 \\
\hline $\mathrm{BU}-2008$ & 0,326 & 1,000 & 0,262 \\
\hline $\mathrm{KV}-2006$ & 1,000 & 1,000 & 1,000 \\
\hline $\mathrm{KV}-2007$ & 0,178 & $0,044^{*}$ & 0,489 \\
\hline $\mathrm{KV}-2008$ & 0,552 & 0,659 & 0,328 \\
\hline $\mathrm{OD}-2006$ & 0,630 & 0,614 & 1,000 \\
\hline $\mathrm{OD}-2007$ & $0,038^{*}$ & $0,027^{*}$ & 1,000 \\
\hline $\mathrm{OD}-2008$ & 0,226 & 0,602 & 0,555 \\
\hline
\end{tabular}

$* a=0,05$

${ }^{1)}$ Phenophases, ${ }^{2}$ Statistical significance between altitudinal zones 
Hoci fenologické pozorovania smreka obyčajného majú dlhú tradíciu a prvé údaje na Slovensku siahajú až do polovice 20. storočia (KuRPELová 1963), mnohé zachytávajú len niektoré fenologické fázy na vegetatívnych orgánoch. Iné literárne pramene (KuBIN et al. 2008) čiastočne poskytujú požadované údaje, ale pre nekompatibilnosê fenologických fáz, a odlišné podmienky prostredia nie je možné tieto výsledky navzájom porovnat.

\section{Záver}

Objasnenie reakcie drevín na zmeny podmienok prostredia je v súčasnosti aktuálnou témou z hladiska zachovania ich vitality a d’alšej reprodukcie. Výsledky trojročných fenologických pozorovaní 20 pôvodov smreka obyčajného (Picea abies [L.] Karst.) z nadmorských výšok 500-1 450 metrov rastúcich v podmienkach Arboréta Borová hora v Zvolenskej kotline podávajú prvé informácie fenologickej reakcie ich generatívnych orgánov na zmenené podmienky prostredia. Podla metodiky SHMÚ používanej pre fenologické pozorovania lesných drevín na Slovensku sme sledovali nástup a priebeh fenologických fáz na generatívnych orgánoch. Hodnotili sme $10 \%$ nástup fenologických fáz pučania ihlicových púčikov, butonizáciu, kvitnutie a odkvet, ako aj dížku ich trvania. Pučanie kvetných púčikov trvalo priemerne od 12. do 21. apríla, prevažne prebehlo za 9-11 dní, butonizácia prebiehala v priemere od 23. apríla do 2. mája s najčastejšou dížkou trvania 5-6 dní. Kvitnutie začalo na všetkých pozorovaných skupinách priemerne od 29. apríla do 8. mája, väčšinou trvalo 5-6 dní. Odkvet nastal v priemere od 5. do 17. mája a trval najčastejšie 11-12 dní.

Z celkového hodnotenia fenologických fáz na generatívnych orgánoch smreka možno konštatovał, že ich nástup a priebeh neovplyvňuje nadmorská výška ich pôvodného stanoviš̊a, ale nové podmienky prostredia, na ktoré sa adaptovali. Nadmorská výška pôvodov smreka v podmienkach Zvolenskej kotliny neovplyvnila ani dížku trvania fenologických fáz. Časový posun fenofáz v jednotlivých rokoch závisel od vývoja teplôt vzduchu. Najskorší nástup fenofáz nastal vo väčšine prípadov v roku 2007, najneskorší v roku 2006. Vyrovnanie priebehu teplôt vzduchu v neskoršom jarnom období spôsobilo zníženie variačného rozpätia fenologických fáz kvitnutie a odkvet. Doterajšie výsledky bude potrebné overit pozorovaniami v dlhšom časovom rade, kedy sa zohladní vplyv stanovišta, ale aj pravdepodobné dôsledky klimatických zmien na priebeh fenologických fáz.

\section{Pod'akovanie}

Príspevok vznikol a bol finančne podporený z projektu VEGA MŠ SR: 1/0515/08 a 1/0139/10.

\section{Literatúra}

1. Bagar R., Nekovář J., 2006: Tendence vývoje vegetace v př́írodních lesních oblastech Moravy. In RožNovskÝ J., Litschmann T., Vyskot I. (eds.): Fenologická odezva proměnlivosti podnebí. Brno: ČHMÚ, 23 s. - 2. BAUER Z., 2006: Fenologické tendence složek jihomoravského lužního lesa na příkladu habrojilmové jaseniny (Ulmi-Fraxineta Carpini) za období 1961-2000. Část I. Fenologie dřevin. Meteorologické zprávy, 59(3): 80-85. -3. Hofman J., 1957: Několik výsledků fenologických pozorovaní a problematika lesnické fenologie. Zbraslav - Strnady: VÚLH, Práce výzkumních ústavů lesnických 
ČSR, zv. 12, s. 67-109. - 4. KolekTív, 1984: Návod pre fenologické pozorovanie lesných rastlín. Bratislava: SHMÚ, 23 s. - 5. Kubin E., Pudas E., Venäläinen A., Terhivuo J., 2008: Phenological recording in Finland. In NeKovÁr̆, J. et al. (eds.): The history and current status of plant phenology in Europe. Finland, Vammalan Kirjapaino, 182 p. - 6. Kurpelové M., 1963: Fenologická charakteristika vysoko položených kotlín na Slovensku. Geografický časopis, 15: 241-263. - 7. LARCHER W., 1988: Fyziologická ekologie rostlin. Praha: Academia, 368 s. - 8. Melo M., 2006: Vplyv geografickej polohy na nástup fenologických fáz lipy malolistej na Slovensku. In RožnovskÝ J., Litschmann T., Vyskot I. (eds.): Fenologická odezva proměnlivosti podnebí. Brno: ČHMÚ, 9 s. - 9. Menzel A., Estrella N., Heitland W., Susnik A., Schleip CH., Dose V., 2008: Bayesian analysis of the species-specific lengthening of the growing season in two European countries and the influence of an insect pest. Int. J. Biometeorol., 52: 209-218. - 10. Petrovič Š., 1972: Klimatické a fenologické pomery Stredoslovenského kraja. Praha: PHMÚ, 432 p. - 11. Priwitzer T., Bucha T., KoreŇ M., 2009: Využitie vegetačného indexu NDVI odvodeného z modisu pri fenologických pozorovaniach lesných porastov. In Bucha T., Pavlendová H. (eds.): Dialkkový prieskum Zeme - lesy v meniacich sa prírodných podmienkach. NLC-LVÚ Zvolen, s. 51-64. - 12. ŠKVARENINOvÁ J., 2003: Analýza fenologických pozorovaní vybraných lesných drevín v Zvolenskej pahorkatine. Acta Facultatis Forestalis, 45: 29-40. - 13. ŠKvareninové J., 2009a: Priebeh vegetatívnych fenologických fáz autochtónnych populácií smreka obyčajného (Picea abies [L.] Karst.) zo Slovenska. Lesnícky časopis-Forestry Journal, 55(1): 13-27. - 14. ŠKVARENINOVÁ J. (ed.), 2009b: Fenológia rastlín v meniacich sa podmienkach prostredia. Zvolen: vydavatelstvo Technickej univerzity, 103 s. - 15. ŠTEFANČík I., 1995: Fenológia v lesníctve 2. Ukončenie vegetačnej činnosti. Lesnícky časopis-Forestry Journal, 41(3): 193-198.

Summary

The explanation of tree-species reactions to the environmental changes is an actual topic from both their preservation as well as next reproduction point of views. The results of 3 years lasting phenological observations of 20 provenances of Norway spruce (Picea abies [L.] Karst.) taken from the altitudinal range of 500-1,450 m and growing under conditions of the Arboretum of Borova Hora situated in the Zvolen basin provide the first information about their phenological response of their generative organs to the changed conditions of the environment. The start and course of particular phenological stages of the generative organs development were observed according to the methodology applied by the Slovak Hydro-Meteorological Institute. There were evaluated the 10\% start of the phenological stages concerning a needle buds bursting, the formation of flowers before blossoming, flowering and blossom fall as well as duration of these periods. Flower buds swelling was lasting on average from $12^{\text {th }}$ till $21^{\text {st }}$ April, it means 9 to 11 days, the formation of flowers before blossoming lasted on average from $23^{\text {rd }}$ April till $2^{\text {nd }}$ May, what is 5 or 6 days. Flowering started in all observed groups, on average, from $29^{\text {th }}$ April till $8^{\text {th }}$ May, what was 5 or 6 days. Blossom fall occurred on average from $5^{\text {th till }} 17^{\text {th }}$ May and lasted for 11 or 12 days.

The evaluation of observed phenological stages of spruce shows that the altitude of their original sites influences neither their beginnings nor courses. The investigated spruce provenances successfully adapted to the growing conditions of a new site. The altitude of spruce provenances under the conditions of the Zvolen basin did not influence the duration of particular phenological stages as well. Time shifts of observed phenological stages in particular years depended on the development of air temperature. The earliest beginnings of phenophases occurred mostly in 2007, the latest ones in 2006. The equalization of air temperature development during the later spring periods decreased the range of dispersion concerning both the phenological stages of flowering and blossom fall. If it is necessary to verify the obtained results by longer lasting observations, when can be revealed also the influence of a site including expected impacts of a climate change on the development of phenological stages.

Translated by: author Revised by: Z. AL-ATTASOVÁ 